\title{
Is Accounting Information Still Relevant in the Internet Age? Research on the Determination of the Effect of Google Trends Data on Earnings Response Coefficient: Case of Vietnam
}

\author{
Nguyen Duy Kieu Phung (Corresponding author) \\ Faculty of Business and Economics, University of Melbourne \\ Tel: +61-432-883-579 E-mail: ndkphung94@gmail.com
}

\begin{abstract}
Nguyen Duy Can
Dept. of Rural Socio-economics, College of Rural Development, Can Tho University

Campus II, 3/2 Street, Ninh Kieu district, Can Tho City, Vietnam

Tel: +84-918-670-578Ｅ-mail: ndcan@ctu.edu.vn
\end{abstract}

Received: October 22, 2019 Accepted: November 20, 2019 Published: November 26, 2019

doi:10.5296/jad.v5i3.15924 URL: https://doi.org/10.5296/jad.v5i3.15924

\begin{abstract}
When determining the role of accounting information, earnings response coefficient (ERC) is usually used for discovering the relationship between new earning information and unexpected share returns in relation to the event of releasing financial statements. In the context that most of the firm-related information is now available for investors via Internet platform, this study addresses the question how the public attention of the company through the Internet affects the response of the market to the accounting information releasing, or in other words, how market reaction to the firm's unexpected earnings is affected by Internet information trends. Using a sample of VN30 baskets of Vietnamese listed firms (excluding the financial institutions) in the Ho Chi Minh Stock Exchange (HOSE) from 2015 to 2018 and the Google trends data from the same period, the study examines investigate the possible relationship between Google trend and the earnings response coefficient. The results from regression indicate that the ERCs of Vietnamese firms is positive and the interest of the firms on the Internet has no significant impact on ERC. The main findings expecting to contribute
\end{abstract}


to providing direct support that the relevance of accounting information are still valuable in the Internet age. This paper is expected to make a contribution to research of accounting information relevance in terms of extending to sample in developing countries like Vietnam.

Keywords: Earnings response coefficient, Google trends data, Accounting information

\section{Introduction}

\subsection{Background and Research Motivation}

Is accounting information still relevant in the Internet age? This is the big question that economists and investors have been concerned. When participating in the stock market, investors make lots of decisions about whether should buy or sell the shares, what kind of shares worth investing, or the number of shares involved in the transactions. The Efficient Market Hypothesis (EMH) suggested that stock prices are unbiased relative to publicly available information and driven by new, unexpected information (Fama, 1970). In the assumption of market efficiency, Ball and Brown (1968) found the sign of information through the earnings announcement (good or bad news) affects the direction of the stock price. From this pioneering research, the importance of the earnings information which is shown in the Financial statement is highlighted in terms of convert inside, private information into publicly available information that investor that get assess to, helping investors to reduce their uncertainty about the future outcome of the market (Scott, 2015). It is also noticeable that when more information of about the firms available on the Internet in recent years, how the investors use the Internet to assist their trading purposes can significantly change the stock market movement (Bijl et al., 2016). By extending to sample in developing countries like Vietnam, this paper contributes to the literature of accounting information relevance in the Internet age.

\subsection{Research Objectives}

This situation arises the question that if firms attract more attention of the investors through Internet, whether the information provided by accountants still can be considered as "new" or "unexpected" enough to have an impact on share price movement. Especially in Vietnam, the high-speed development of economic and technology lead to the evolvement of the stock market (Meifen, 2016). Therefore, doing research to determine the direct impact of the trend of the search engines on the magnitude of security price response to earning information can contribute to explain the value relevance of the accounting information under the Internet age.

\subsection{Research Structure}

The remaining of this paper follows the structure: Section 2 give the literature review; Section 3 describes the sample selection and methodology; Section 4 describes the sample data using in this paper and its' statistical properties and also reports the empirical results. Section 5 provides conclusions.

\section{Literature Review}




\section{$\Lambda$ Macrothink}

The role of accounting has been an important topic in the literature. In primary research, the relationship between the announcements of earning news with changes in stock prices was mentioned as one of the most important evidence of the usefulness of accounting information (Ball and Brown, 1968). To explain the different the magnitude of the reaction of the market to accounting earnings information and to compare them across firms and time, the empirical research suggested measuring earnings response coefficient (ERC), which is the regression slope coefficient between unexpected earnings with an abnormal return of stock (Scott, 2015). In this context, the abnormal return is the return of the stock on firm-specific reason or the return which does not affect by the market-wide factors, calculating by the actual return excluding the expected return of the stock (Shapiro, 1990). Similarly, unexpected earnings (instead of total earnings) reflects new information containing in the financial statement, showing by the difference between the actual and expectation (Scott, 2015). There are several causes why ERC or the market response to earnings new varies have been researched through recent year, including earnings persistence (Kormendi \& Lipe, 1987), capital structure (Dhaliwal et al., 2010), the firm's risk, company chance of growth and firm size (Collins and Kothari, 1989). Yet the empirical results about the effect are inconsistent. The higher the ERC value, the stronger the reaction and higher the usefulness of the information contained in the financial report and conversely. Studies on ERC align with the decision theory when the published a piece of market information will assist the rational investors to make investment decisions by reducing information asymmetry and uncertainty with signals shown financial statements.

Meanwhile, with the increased popularity and evolution of technology, many information of the firm has become more accessible to the public through online resources. (Weng et al., 2018). By giving out more information to investors, especially to individual ones who traditionally have less information, the reduction of information asymmetry among the different participants in the capital market (Bushee et al., 2010). In addition, content and the tone of communication of the news influence investors' expectations about the future stock price. Hence, it is reasonable to expect the innovation on the technology narrow down the information gap with more informed investors. Under this circumstance, Google Trends search data provides information on the change volume of searching (the number of queries) for specific search terms over time. This search tool gives information about the frequency or attention of the public through specific keywords over a specific period (Weng et al., 2018).

It is also noted that investor attention influences the market's reaction to earnings information. (Drake et al. 2012). The impact of internet search on earnings response coefficients is showed through bid-ask spreads, trading volumes, and returns of the stocks around earnings announcements. The difference is explained by the bias and information advantage reasons. (Chi \& Shanthikumar, 2017). There is also evidence of limiting individual investors' ability to conduct internet searches would negatively impact trading activities (Brown et al., 2015). Wikipedia information about the firms affected how investors react to bad news (Xin \& Zhang, 2013). Besides, the effects of information asymmetry are mitigated by press coverage when it help investor reduces information mispricing of (Drake et al., 2014). When the volume of Google search is influenced by the news of the realizing of the earnings 
announcement, it is suggested that investors want to know more about a firm. (Drake et al. 2012). Individual information demand using daily Google searches helps to mitigate market ambiguity around earnings announcement (Hasan, et al., 2018)

When an investor searches the company name on Google, they would get the new information about the company, leading them to become more informative due to the more they search for the information. This would give rise to the question that to what extent does this trend affecting the value relevance of the accounting information. However, there are very limited studies about whether more information the public gets would impair or highlight the importance of earning announcements.

Regarding the above matters, the main purpose of this study was to investigate the relationship between earnings response coefficients and the public interest of the firm on the Internet which is reflected in Google data of in Vietnamese companies listed on the Ho Chi Minh Stock Exchange.

\section{Research Methods}

\subsection{Empirical Model}

According to Collins and Kothari (1989), events study (narrow-window approach) or an association study (wide-window approach) is either used for the correlation investigation. Event studies are defined as studies the change of stock returns in the short time period (2-3 days) of an earnings event. The association, which investigates the behavior of stock prices and earnings over long periods (fiscal quarters or year) recognized that investors learn about earnings information from sources throughout the period. Therefore, the wide approach would be more suitable for the purpose of this study. Adopting the model suggested in the paper of An (2015), the information content of earnings are derived from the significance of the slope coefficient $\beta$ and explanatory power:

$$
\mathrm{CAR}_{\mathrm{it}}=\alpha+\beta^{*} \mathrm{UE}_{\mathrm{it}}+\varepsilon_{\mathrm{jt}}(1)
$$

Where:

- CAR is cumulative abnormal returns of firm $\mathrm{i}$ over period $\mathrm{t}$, measuring as accumulating abnormal returns (AR) of the firm I over the 12 months that correspond with the fiscal period.

$$
\mathrm{CAR}_{\mathrm{i}}=\sum \mathrm{AR}_{\mathrm{i}}=\sum \mathrm{R}_{\mathrm{it}}-\mathrm{R}_{\mathrm{mt}}
$$

- $\mathrm{R}_{\mathrm{it}}$ is the stock return company $\mathrm{i}$ in period $\mathrm{t}$, derived by the log return on closing price

- $\mathrm{R}_{\mathrm{mt}}$ is the market return company $\mathrm{i}$ in period $\mathrm{t}$, derived by the $\log$ return Composite Index (VN Index)

- $\mathrm{UE}_{\mathrm{it}}$ is a measure of unexpected earnings, measuring the change in Earning per share (EPS) with random walk model

$$
\mathrm{UE}_{\mathrm{it}}=\ln \left(\mathrm{EPS}_{\mathrm{it}} / \mathrm{EPS}_{\mathrm{it}-1}\right)
$$


- $\mathrm{EPS}_{\mathrm{it}}=$ Earnings per share for firm $\mathrm{i}$ in period $\mathrm{t}$

- $\mathrm{EPS}_{\mathrm{it}-1}=$ Earnings per share for firm $\mathrm{i}$ in period $\mathrm{t}-1$

- $\beta$ is the coefficient of the regression, resulting ERC

Hypothesized that ERC is affected by the public interest of the firm on the Internet, which is measured by Google Trend data, the following regression model tests:

$$
\mathrm{ERC}_{\mathrm{it}}=\alpha+\beta^{*} \mathrm{~T}_{\mathrm{it}}+\varepsilon_{\mathrm{jt}}(2)
$$

Where:

- $\mathrm{ERC}_{\mathrm{it}}$ is the earning response coefficient of firm $\mathrm{i}$ at $\mathrm{t}$ period

- $\mathrm{T}_{\text {it }}$ natural logarithm of cumulation search volume of stock name on Google

Combine (1) and (2) and expand with the factors that affect REC in previous research including: capital structure (Dhaliwal et al., 2010), company chance of growth (Collins and Kothari, 1989), the model used in this study is as follow:

$$
\mathrm{CAR}_{\mathrm{it}}=\alpha+\beta_{1} * \mathrm{UE}_{\mathrm{it}}+\beta_{2} * \mathrm{~T}_{\mathrm{it}} * \mathrm{UE}_{\mathrm{it}}+\beta_{3} * \mathrm{G}_{\mathrm{it}}{ }^{*} \mathrm{UE}_{\mathrm{it}}+\beta_{4} * \mathrm{C}_{\mathrm{it}} * \mathrm{UE}_{\mathrm{it}}+\varepsilon_{\mathrm{jt}}(3)
$$

Where:

- $\mathrm{G}_{\mathrm{it}}$ is growth opportunity measured from the market to book ratio

- $\mathrm{C}_{\mathrm{it}}$ company's capital structure is leverage ratio of total debt (liabilities) to the total assets of the company

Our main variable of interest is $\beta_{1}$ which is the ERC and $\beta_{2}$, coefficient of $T_{i t}{ }^{*} \mathrm{UE}_{\mathrm{it}}$ captures impact of the search volume on ERCs.

\subsection{Sample Selection}

The sample for the study consists of listed stocks in VN30 baskets (excluding the financial institutions) in the Ho Chi Minh Stock Exchange (HOSE) during the three-year period from 2016 to 2018. The reason for choosing period is that in the stock market and technology in Vietnam have developed to be more utilized by Vietnamese investors through recent years The sample- firms are chosen from newest updated of VN30 basket which is top 30 large-cap, liquid stocks in the HOSE market for a presentative reason. The financial institutions were excluded due to the unique characteristics of the capital structure. Data about the stock return, earning, market and book value ratio, and the capital structure was obtained from the official website of HOSE (https://www.hsx.vn). The data of the search volume of the company stock name was taken from the Google trend database from the website (https://trends.google.com).

\section{Results and Discussion}

\subsection{Data Description and Sample Statistics}

Descriptive statistics are shown in the table below. The mean value of CAR is negative, 


\section{Macrothink}

Journal of Asian Development

ISSN 2377-9594 2019, Vol. 5, No. 3

reflecting the poor performance of Vietnamese firms in the stock market in the recent year. The standard deviation results show that the abnormal stock return has low volatility, representing a well-controlled market. Regarding the unexpected earning, it is shown that UE also shares the same feature with CAR when the mean is negative, and the standard deviation is not significant. The mean the ratio of $\mathrm{L} / \mathrm{A}<50 \%$ shows a not so leverage capital structure of Vietnamese firms. The logarithm of the volume of search queries on Google did not volatile significantly.

Table 1. Data description

\begin{tabular}{llllll}
\hline & $C A R$ & $U E$ & $P / B$ & $L / A$ & $T$ \\
\hline Mean & -0.111 & -0.005 & 3.395 & 0.451 & 7.115 \\
Standard Error & 0.050 & 0.082 & 0.429 & 0.024 & 0.082 \\
Standard Deviation & 0.351 & 0.578 & 3.030 & 0.169 & 0.577 \\
Minimum & -1.397 & -2.775 & 0.830 & 0.140 & 5.656 \\
Maximum & 0.624 & 0.954 & 15.130 & 0.754 & 8.147 \\
\hline
\end{tabular}

* Tests for correlation and multi multicollinearity test (see more in Appendix) for the input is shown that the model is free from problems to perform an ordinary linear regression (OLS).

\subsection{Result analysis}

With the model CAR $\mathrm{Cit}_{\mathrm{it}}=\alpha+\beta_{1} * \mathrm{UE}_{\mathrm{it}}+\beta_{2} * \mathrm{~T}_{\mathrm{it}} * \mathrm{UE}_{\mathrm{it}}+\beta_{3} * \mathrm{G}_{\mathrm{it}} * \mathrm{UE}_{\mathrm{it}}+\beta_{4} * \mathrm{C}_{\mathrm{it}} * \mathrm{UE}_{\mathrm{it}}+\varepsilon_{\mathrm{jt}}$

And using of OLS technique, regression results in presented in the table below from the model * 
Table 2. Result from regression

\begin{tabular}{lll}
\hline & Coefficients & P-value \\
\hline Intercept & -0.09667 & 0.065437 \\
$\mathrm{UE}$ & 1.127938 & 0.020799 \\
$\mathrm{UE}{ }^{*} \mathrm{G}$ & -0.019 & 0.631703 \\
$\mathrm{UE}{ }^{*} \mathrm{C}$ & -1.39854 & 0.044563 \\
$\mathrm{UE} * \mathrm{~T}$ & -0.01321 & 0.673896 \\
$\mathrm{R}$ Square & 0.232177 & \\
Adjusted R Square & 0.163926 & \\
Significance F & 0.01630963 & \\
\hline
\end{tabular}

From the results, the value of $\mathrm{R}$ Square and Adjusted R Square is 23\% and 16\% respectively, indicated that stock market return cannot be explained through only accounting information and ratio. It can be because that market is not fully efficient to reflect all the information. The significance level of $\mathrm{F}$ value 0.016 means the model is suitable (at $5 \%$ level significant). Earnings Response Coefficient (ERC) is equal to the coefficient of UE, with a positive value of nearly 1.13 (significance level of 5\%). This is consistent with the previous ERC result of Ball and Brown (1986), Dhaliwal et al (2010) and Collins and Kothari (1989) when the positive unexpected earnings lead to a positive abnormal rate of return on average and negative unexpected earnings lead to a negative abnormal rate of return. The results are important when it again confirms the role of accounting in the Vietnamese market to providing useful information to make decisions.

The negative coefficient of $\mathrm{UE}^{*} \mathrm{C}$ also proves that capital structure has a significant negative effect on the ERC give the same conclusion as Dhaliwal et al (2010). Investors will less react to the earnings information if the leverage (Liabilities/Assets ratio) is high, in other words, more debt in the firm's capital structure. This phenomenon is explained that the good news for earning seems to be more valuable to debt holders than the equity holders (Scott, 2015), therefore, the investors are less interest with the earnings news. The results are shown that are company growth (market to book ratio) has a negative effect on the ERC but not statistically significant. The explanation that can be given is that growth opportunities imply a long-term prospect in a company rather than the short-term benefits, so investor decision may not be affected.

The public interest in search engines like Google also negative influence not statistically significant on ERC. It could be because the information on the Internet that investor can get is very voluminous, complex and complicated. Vietnamese investor may be more conservative and cautious with that information and thus, their behaviour on the traditional, 
"more reliable" were not affected. The results strengthen the value-relevance role of accounting in investment decision making even through in the age that more and more Internet utilization.

\section{Summary and Conclusion}

In the setting that the greater part of the firm-related data is presently accessible for financial specialists on Internet stage, this study examines whether the use of the Internet to search for new information affect the Investor decision related to earning by testing regression between ERC and Google trend search data. Sampling of selected Vietnamese firms (excluding the financial institutions) in the VN30 basket of Ho Chi Minh Stock Exchange (HOSE) and the Google trend data information from a 3 year period, the results finds the positive ERC, suggesting that the investors direction of reaction on the market based on the signal of the news that accountants provide. This reaction is also affected by the capital structure of the firms. However, the connection between new gaining data on the Internet by the search on Google and the reaction of the investor are not established. This shows that Internet information is not informative enough to influences the reaction of the market to income. The discoveries highlight the importance of an accountant in terms of usefulness's creation in the Internet age. Several related issues have remained and there is a need for future research, including the simplified model ignores the cross-sectional and time-series affect, and Google Trends data does not fully reflect the usage of investor on the Internet which is now the combination of lots of different platform like Wikipedia, Social Media.

\section{References}

An, Y. (2015). Earnings Response Coefficients and Default Risk: Case of Korean Firms. International Journal of Financial Research, 6, 67.https://doi.org/10.5430/ijfr.v6n2p67

Ball, R., \& Brown, P. (1968). An Empirical Evaluation of Accounting Income Numbers. Journal of Accounting Research, 6, 159-178. https://doi.org/10.2307/2490232

Bijl, L., Kringhaug, G., Molnár, P., \& Sandvik, E. (2016). Google searches and stock returns. International Review of Financial Analysis, 45, 150-156. https://doi.org/10.1016/j.irfa.2016.03.015

Brown, N. C., Stice, H., \& White, R. M. (2015). Mobile communication and local information flow: Evidence from distracted driving laws. Journal of Accounting Research, 53(2), 275-329. https://doi.org/10.1111/1475-679X.12077

Bushee, B. J., Core, J. E., Guay, W., \& Hamm, S. J. W. (2010). The Role of the Business Press as an Information Intermediary. Journal of Accounting Research, 48, 1-19. https://doi.org/10.1111/j.1475-679X.2009.00357.x

Chi, S., \& Shanthikumar, D. (2017). Local Bias in Google Search and the Market Response around Earnings Announcements. The Accounting Review, 92(4), 115-143. https://doi.org/10.2308/accr-51632

Collins, D. W., \& Kothari, S. P. (1989). An analysis of intertemporal and cross-sectional 


\section{Macrothink Institute ${ }^{\text {TM }}$}

determinants of earnings response coefficients. Journal of Accounting and Economics, 11, 143-181. https://doi.org/10.1016/0165-4101(89)90004-9

Dhaliwal, D., Lee, K., \& Fargher, N. (2010). The association between unexpected earnings and abnormal security returns in the presence of financial leverage. Contemporary Accounting Research, 8, 20-41. https://doi.org/10.1111/j.1911-3846.1991.tb00832.x

Drake, M. S., Roulstone, D. T., \& Thornock, J. R. (2012). Investor Information Demand: Evidence from Google Searches Around Earnings Announcements. Journal of Accounting Research, (4), 1001. https://doi.org/10.1111/j.1475-679X.2012.00443.x

Drake, M., Guest, N., \& Twedt, B. (2014). The Media and Mispricing: The Role of the Business Press in the Pricing of Accounting Information. The Accounting Review, 89(5), 1673-1701. https://doi.org/10.2308/accr-50757

Fama, E. F. (1970). Efficient Capital Markets: A Review of Theory and Empirical Work. The Journal of Finance, 25, 383-417. https://doi.org/10.2307/2325486

Hasan, R., Kumas, A., \& van der Laan Smith, J. (2018). Market ambiguity and individual investor information demand. Journal of Contemporary Accounting \& Economics, 14(1), 126-141. https://doi.org/10.1016/j.jcae.2018.03.001

Meifen CHU (2016). A Comparative Study of Vietnam and China Stock Market. Annual International Conference on Qualitative \& Quantitative Economics Research, 56-63. https://doi.org/10.5176/2251-2012_QQE16.36

Roger, K., \& Robert, L. (1987). Earnings Innovations, Earnings Persistence, and Stock Returns. The Journal of Business, 60, 323. https://doi.org/10.1086/296400

Scott, W. R. (2015). Financial accounting theory (7th ed.). Pearson Canada.

Shapiro, A. C. (1990). Modern corporate finance. Macmillan.

Xin Xu, S., \& Xiaoquan (Michael), Zhang. (2013). Impact of Wikipedia on Market Information Environment: Evidence on Management Disclosure and Investor Reaction. MIS Quarterly, 37(4), 1043-A10. https://doi.org/10.25300/MISQ/2013/37.4.03

Weng, B., Lu, L., Wang, X., Megahed, F. M., \& Martinez, W. (2018). Predicting short-term stock prices using ensemble methods and online data sources. Expert Systems with Applications, 112, 258-273. https://doi.org/10.1016/j.eswa.2018.06.016 
Appendix

Appendix 1

\begin{tabular}{llcr}
\hline & \multicolumn{3}{c}{ Collinearity Statistics } \\
\cline { 3 - 4 } Model & Tolerance & VIF \\
\hline 1 & (Constant) & & 1.020 \\
& $\mathrm{G}$ & .981 & 1.018 \\
& $\mathrm{C}$ & .982 & 1.043 \\
& $\mathrm{~T}$ & .959 & 1.034 \\
\hline
\end{tabular}

The result of multicollinearity test shows that the VIF value less than 10 . It is means that there is no multicollinearity.

Appendix 2

\begin{tabular}{|c|c|c|c|c|c|c|}
\hline & & CAR & $\mathrm{G}$ & $\mathrm{C}$ & $\mathrm{T}$ & UE \\
\hline Pearson & CAR & 1.000 & -.063 & -.042 & .025 & .398 \\
\hline \multirow[t]{4}{*}{ Correlation } & $\mathrm{G}$ & -.063 & 1.000 & -.060 & -.082 & .112 \\
\hline & $\mathrm{C}$ & -.042 & -.060 & 1.000 & .123 & -.012 \\
\hline & $\mathrm{T}$ & .025 & -.082 & .123 & 1.000 & -.151 \\
\hline & UE & .398 & .112 & -.012 & -.151 & 1.000 \\
\hline \multirow[t]{5}{*}{ Sig. (1-tailed) } & CAR & . & .331 & .386 & .430 & .002 \\
\hline & G & .331 & & .340 & .285 & .220 \\
\hline & $\mathrm{C}$ & .386 & .340 & . & .198 & .466 \\
\hline & $\mathrm{T}$ & .430 & .285 & .198 & & .147 \\
\hline & UE & .002 & .220 & .466 & .147 & \\
\hline
\end{tabular}

CAR has significantly positive correlation with UE. P/B, L/A and T have no correlation with each other and CAR, it is suitable with the hypothesis (i.e. G, C, T only affect the ERC not directly have correlation with CAR) of the study.

\section{Copyright Disclaimer}

Copyright for this article is retained by the author(s), with first publication rights granted to the journal.

This is an open-access article distributed under the terms and conditions of the Creative Commons Attribution license (http://creativecommons.org/licenses/by/4.0/). 